\title{
A Study on Occupational Health Psychology of Employees in IT Sector in Ahmedabad City
}

\author{
Pranav Saraswat \\ Senior Assistant Professor, Institute of Law, Nirma University Ahmedabad
}

\begin{abstract}
In this fast paced global world, human being is surrounded by numerous tensions and various competitors. To survive in this complex world one has to put his whole and sole effort to earn his livelihood. For this he has to do millions of work which causes stress. So employees need to manage stress and remove their occupational illness.

The objective of this research is to determine how occupational health psychology is being handled in IT industry. Along with that I will analyze the importance of stress management from the organizations point of view, identify reasons, effects and stress release strategies. I have used primary data of the IT industry to study how health and safety measures can be taken to remove the mental and physical illness of employees in IT sector. Secondary data is also used for analysis purpose.
\end{abstract}

Keywords: Stress, Occupational Health Psychology, Information technology, Stress Management

\section{Introduction}

The Information technology industry in India has gained a brand identity as a knowledge economy due to its IT and ITES (IT-Enabled Services) sector. TheIT-ITES industry has two major components: IT Services and business process outsourcing (BPO). ${ }^{10}$ The growth in the service sector in India has been led by the IT-ITES sector, contributing substantially to increase in GDP, employment, and exports. The New Telecommunications Policy, 1999 (NTP 1999) helped further liberalize India's telecommunications sector. The Information Technology Act 2000 created legal procedures for electronic transactions and e-commerce. ${ }^{16}$ The success of Information Technology in India not only had economic repercussions but also had far-reaching political consequences. India's reputation both as a source and a destination for skilled workforce helped it improve its relations with a number of world economies. The relationship between economy and technologyvalued in the western world facilitated the growth of an entrepreneurial class of immigrant Indians, which further helped aid in promoting technologydriven growth.India's growing stature in the Information Age enabled it to form close ties with both the United States of Americaand the European Union. However, the recent global financial crises has deeply impacted the Indian IT companies as well as global companies. As a result hiring has dropped sharply, and employees are looking at different sectors like the financial service, telecommunications, and manufacturing industries, which have been growing phenomenally over the last few years. ${ }^{7}$

India's IT Services industry was born in Mumbai in 1967 with the establishment of Tata Group in partnership with Burroughs. The first software export zone SEEPZ was set up here way back in 1973, the old avatar of the modern day IT park. More than 80 percent of the country's software exports happened out of SEEPZ, Mumbai in 80 s. ${ }^{9}$

In this fast paced global world, human being is surrounded by numerous tensions and various competitors. To survive in this complex world one has to put his whole and sole effort to earn his livelihood. ${ }^{1}$ For this he has to do millions of work which causes stress. So employees need to manage stress and remove their occupational illness.

The objective of my research is to determine how occupational health psychology is being handled in IT industry. Along with that I will analyze the importance of stress management from the organizations point of view, identify reasons, effects and stress release strategies. ${ }^{8}$ I 
can also recommend some strategies for future course of action. I have used questionnaire as a research tool to study how health and safety measures can be taken to remove the mental and physical illness of employees in IT sector. Secondary data is collected through internet and magazines. I have done analysis with the help of different charts and used chi-square as a statistical tool.

\section{Literature Review}

A literature review revealed the following: key work factors associated with psychological ill health and sickness absence in staff were long hours worked, work overload and pressure, and the effects of these on personal lives; lack of control over work; lack of participation in decision making; poor social support; and unclear management and work role. ${ }^{3}$ There was some evidence that sickness absence was associated with poor management style. Successful interventions that improved psychological health and levels of sickness absence used training and organisational approaches to increase participation in decision making and problem solving, increase support and feedback, and improve communication.

It is concluded that many of the work related variables associated with high levels of psychological ill health are potentially amenable to change. This is shown in intervention studies that have successfully improved psychological health and reduced sickness absence. ${ }^{6}$

The primary emphasis will be on the development and maintenance of healthy people within healthy organizations focusing on prevention of illness, disease, health problems, and injuries in the work environment. Specific topics covered include occupational safety and health hazards, organization of work factors and their relation to employee safety and health, safety climate and training, the etiology of job stress and burnout, workplace health promotion programs and the role of employee assistance programs, the interface of work and non-work factors in maintaining occupational health. ${ }^{5}$

The Society for Occupational Health Psychology (SOHP) is a learned society with as focal point the "generation, dissemination, and application of scientific knowledge in order to improve worker health and wellbeing." Moreover, understanding the significance of a healthy work environment can directly provide and contribute to work mastery and work ethic. ${ }^{14}$

Employee assistance programs (EAPs) are plans that help identify and resolve issues facing troubled employees through short-term counseling, referrals to specialized professionals or organizations.Occupational health is essentially preventive medicine. ${ }^{12}$ The joint International Labor Organization(ILO) \& World Health Organization(WHO) Committee"occupational healthshould aim at the promotion and maintenance of the highest degree of physical, mental and social well being of the workers/employees in all occupations.

\section{Background of the Study}

A number of individuals contributed to the foundation of OHP. The Industrial Revolution in the nineteenth century prompted thinkers to concern themselves with the nature of work. Marx'stheory of alienation of the industrial worker has been influential. Taylor's (1911) Principles of Scientific Management and Mayo's research in the late 1920s and early 1930s on workers at the Hawthorne Western Electric plant helped to inject work and its impact on workers into the subject matter psychology addresses and contributed to the development of OHP.Since 1950, the International Labour Organization (ILO) and the World Health Organization (WHO) have shared a common definition of occupational health. ${ }^{13}$ It was adopted by the Joint ILO/WHO Committee on Occupational Health at its first session in 1950 and revised at its twelfth session in 1995. OHP is especially concerned with the dramatic transformation of work and employment that has been underway in industrial economies since the 1980s (e.g., flexible employment and production processes), and how changing organizational structures and processes are influencing the health and well-being of workers and their families. ${ }^{4}$

Many psychologists have argued that the psychology field needs to take a more active role in research and practice to prevent occupational stress, illness, and injury. ${ }^{11}$ This is what the new field of Occupational Health Psychology (OHP) is all about.OHP concerns the application of psychology to improving the quality of work life, and to protecting and promoting the safety, health and well-being of workers.

\section{Problem Statement of the Study}

Rapidly changing conditions of work and employment have brought the topic of work organization and health to the forefront of concern in occupational safety and health. ${ }^{2}$ This paper begins with 
a historical overview of psychology's contribution to the occupational safety and health field. It then argues that the changing work environment creates new and special needs for research and application by psychologists in the area of work organization and health.

This problem statement investigates the relationship between the physical and mental health of the employees and different parameters such as job performance, compensation, organization climate and culture etc. ${ }^{15}$

\section{Objectives of the Study}

OHP research examines the impact of work on both physical and mental well-being. Knowledge derived from this research helps researchers and practitioners devise means for improving the lives of people who work.Occupational Health Psychology research and practice aim at developing interventions at individual and organizational level in order to create healthier organizations and healthier employees and to maximize employees' effectiveness and work performance. This can be the excellent opportunity to develop practical skills for working as organizational consultants in multinational environments. The main objective of this research study is know how to:

- To promote and maintain the highest degree of physical, mental and social well-being of workers in all occupations;

- The prevention amongst workers of departures from health caused by their working conditions;

- The protection of workers in their employment from risks resulting from factors adverse to health;

- The placing and maintenance of the worker in an occupational environment adapted to his physiological and psychological capabilities.

\section{Hypothesis}

\section{H0: Occupational health psychology of employees in IT sector is GOOD}

\author{
H1: Occupational health psychology of employees \\ in IT sector is not GOOD
}

\section{Research Methodology}

\section{Sources of Data}

Interaction with Respondents was in the form of face-to-face interviews with the help of questionnaire. The questionnaire consisted of a set of questions, asked to the respondent for his/her response, the questionnaire was structured and non-disguised. It was done in a prearranged order and the object of the research was revealed to the respondent. The questionnaire consisted of combination of open ended and close-ended question.

\section{Primary Data}

The primary data was generated through extensive use of a structured questionnaire, which had both the open end and close-ended questions.Primary data is facts and information collected specifically for the purpose of the investigation at hand.

\section{Primary Data}

- Questionnaire

- Interviews with employees

\section{$\underline{\text { Secondary Data }}$}

Secondary sources are research reports that use primary data to solve research problems.Secondary data has been gathered by others for their own purposes, but the data could be useful in the analysis of a wide range of real property. In general, secondary data exists in published sources.

\section{$\underline{\text { Secondary Sources }}$}

- Internet

- Magazine

- Newspapers and Journals

According to the Survey conducted on over 150 IT professional the various findings are as under.

Various factors which cause the occupational health psychological issues are found to as shown in the graph amongst all this , as per chart no. 1 Heavy workload given to the employee is the major factor that causes stress on high level and apart from that and work schedules and work delegation are the factors which causes moderate level of stress to the majority of people. 


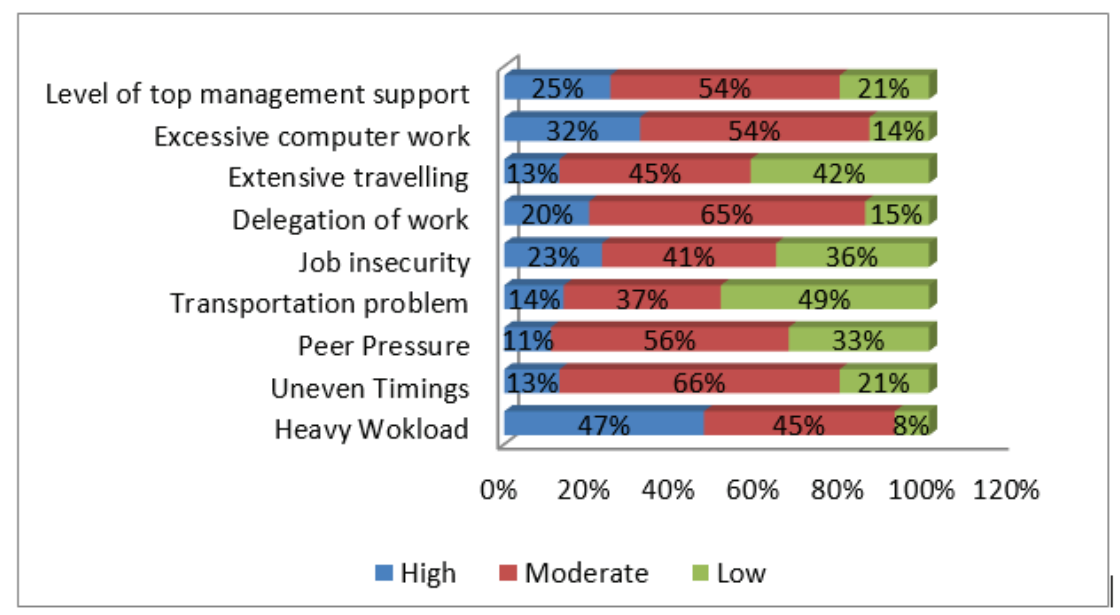

Chart. 1. Causes of Occupational Health Pschology

- During the survey that, in the ITindustry, the highest number of hazards i.e $66 \%$ are of technological types Viz excessive use of computers, the telephonic sounds etc.besides that $39 \%$ are affected by the psychological hazards.As per the chart no. 2 , The lowest we found the percaentage of physical hazards.

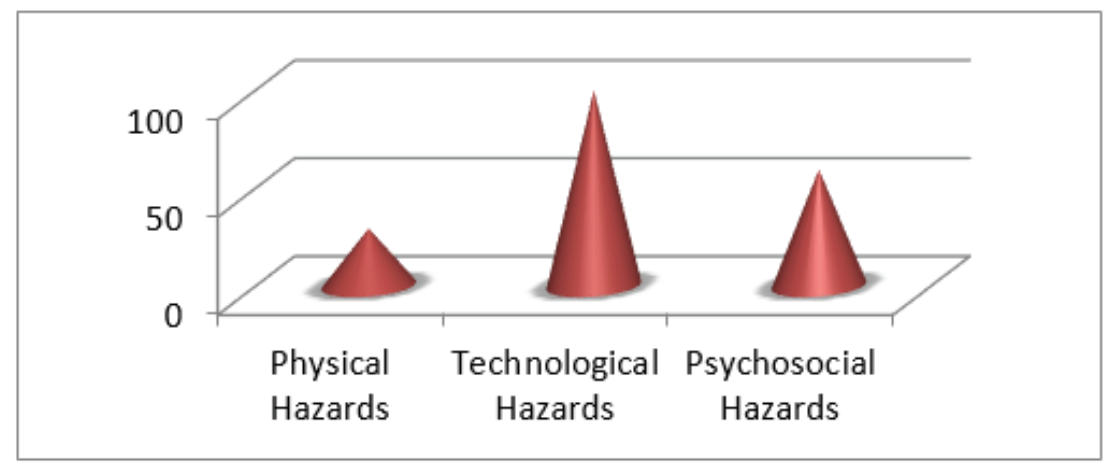

\section{Chart. 2. IT Industry Hazards}

- As per chart no. 3 we found that almost $48 \%$ respondents face job burnout due to excessive work and high pressure where as rest of the people never faced job burnouts. The other reasons for job burnouts may be unclear requirements, lack of personal control, poor communication, and insufficient compensation.

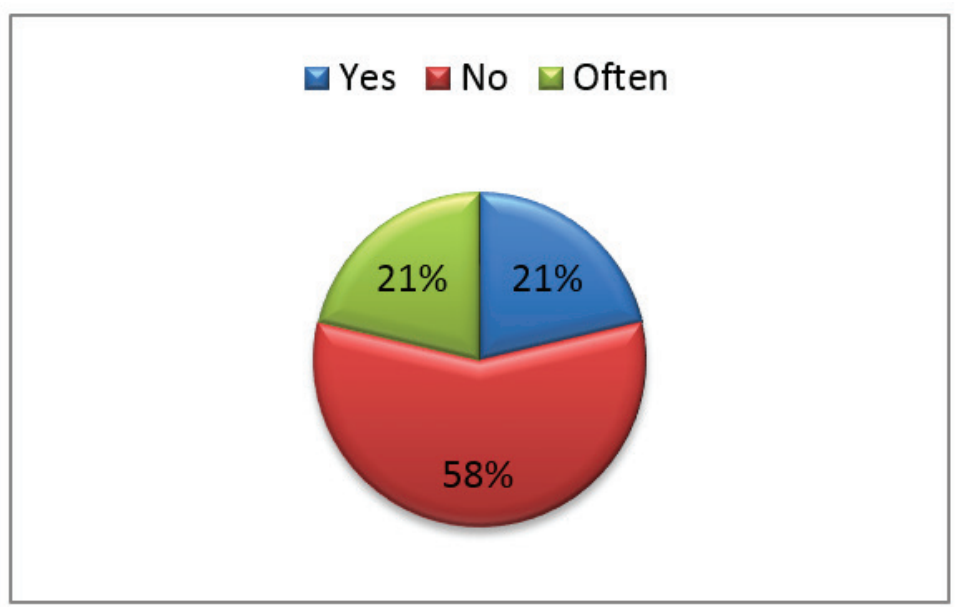

Chart. 3.Job burn out 


\section{Hypothesis Testing}

Pearson's chi-squared test between the Monthly Income and the Job Burnouts due to excessive stress and work pressure.

H0: Income Level and Job burnouts are independent of each other.

H1: Income Level and Job burnouts are dependent of each other.

Table. 1. Monthly Income and Job burnout

\begin{tabular}{|c|c|c|c|c|c|}
\hline \multirow[b]{2}{*}{$\begin{array}{c}\text { Job } \\
\text { Burnouts }\end{array}$} & \multicolumn{4}{|c|}{ Monthly Income (in Rs) } & \multirow[b]{2}{*}{ Total } \\
\hline & $\begin{array}{c}\text { Less than } \\
10,000\end{array}$ & $10,000-20,000$ & $\begin{array}{r}20,000- \\
30,000\end{array}$ & $\begin{array}{l}\text { Above } \\
30,000\end{array}$ & \\
\hline Yes & 4 & 15 & 7 & 6 & 32 \\
\hline No & 9 & 26 & 33 & 18 & 86 \\
\hline Often & 3 & 11 & 9 & 9 & 32 \\
\hline Total & 16 & 52 & 49 & 33 & 150 \\
\hline
\end{tabular}

Table. 2. Chi-Square Tests

\begin{tabular}{|l|c|c|c|}
\hline & Value & df & Asymp. Sig. (2-sided) \\
\hline $\begin{array}{l}\text { Pearson } \\
\text { Chi- } \\
\text { Square } \\
\begin{array}{l}\text { Likelihood } \\
\text { Ratio }\end{array}\end{array}$ & $\mathbf{4 . 9 6 2 ~}^{\mathrm{a}}$ & $\mathbf{6}$ & $\mathbf{0 . 5 4 9}$ \\
$\begin{array}{l}\text { Linear-by- } \\
\text { Linear } \\
\text { Association }\end{array}$ & 4.924 & 6 & 0.554 \\
$\begin{array}{l}\text { N of Valid } \\
\text { Cases }\end{array}$ & 1.432 & 1 & 0.231 \\
\hline
\end{tabular}

\section{Interpretation}

$0.05<0.549$ So H0 is Accepted.

Hence : Alternative Hypothesis H1 is Rejected

Hence the Income Level does not affect the level of Job burnouts and thus they are independent of each other.

Pearson's chi-squared test between the Overall satisfaction level and the adoption of changes in the working environment.

H0: Overall satisfaction level and adoption of changes are independent of each other.

H1: Overall satisfaction level and adoption of changes are dependent of each other. 
Table. 3. Overall satisfaction Level

\begin{tabular}{|c|c|c|c|c|c|}
\hline \multirow{2}{*}{ Adoption of changes } & \multicolumn{3}{|c|}{ Overall satisfaction level } & \multirow[b]{2}{*}{ Dissatisfied } & \multirow[b]{2}{*}{ Total } \\
\hline & $\begin{array}{l}\text { Highly } \\
\text { Satisfied }\end{array}$ & Satisfied & Neutral & & \\
\hline 1 & 14 & 80 & 14 & 1 & 109 \\
\hline 2 & 0 & 0 & 7 & 0 & 7 \\
\hline 3 & 4 & 12 & 17 & 1 & 34 \\
\hline Total & 18 & 92 & 38 & 2 & 150 \\
\hline
\end{tabular}

Table. 4. Chi-Square Tests

\begin{tabular}{|l|c|c|c|}
\hline & Value & Df & $\begin{array}{c}\text { Asymp. Sig. (2- } \\
\text { sided) }\end{array}$ \\
\hline Pearson Chi-Square & $\mathbf{4 2 . 7 2 0 ^ { \mathrm { a } }}$ & $\mathbf{6}$ & $\mathbf{0 0 0}$ \\
Likelihood Ratio & 41.361 & 6 & .000 \\
Linear-by-Linear Association & 14.673 & 1 & .000 \\
\hline
\end{tabular}

\section{Interpretation}

$0.05<0.000$ So H0 is Rejected.

Hence : Alternative Hypothesis H1 is Accepted. Thusoverall satisfaction level and adoption of changes are dependent of each other.

- Also I found that the age and gender does not affect the various factors which causes the occupational health psychological issues.

- I also found that a very less proportion of people are dis-satisfied with the income, reward and working environment of the companies.

- Out of 150 employees which I have surveyed, $71 \%$ of them are using work life policies provided by the organization, $29 \%$ of them do not use any kind of work life programs
- $\quad 91 \%$ of them are able to manage their personal and professional life

\section{Conclusion of the Study}

Ahmedabad city is a fast developing city with all the amenities and facilities available. People of Ahmedabad lead a good life. After conducting the research in the city of Ahmedabad on the IT professional, I found that the there are some issues related to physical and psychological health but in manageable condition. Overall OHP of these employees can be considered as good enough and it can be improved taking initiatives using stress management techniques, physical fitness maintenance, technological monitoring etc.

\section{Limitations of the Study}

- The opinion expressed is on response based.

- The sample size of model might not represent 
perception of whole population as the sample size is small.

- The attitude of research might be biased.

- There is limitation of geographical research. As we know that the study is being carried out of the people of Ahmedabad only so a wider aspect and the wider scenario would be missing

- Last but not the least is that incomplete questionnaire, it is also a limitation means everyone is not taking interest in filling up the questionnaire.

\section{Conflict of Interest- No}

\section{Source of Funding - Self}

Ethical Clearance - NA

\section{References}

1) Houdmont J, Leka S. Occupational health psychology: European perspectives on research, education and practice. Nottingham University Press; 2008.

2) Schabracq M, Cooper CL, Maanen DV. Occupational health psychology: the challenge of workplace stress. Leicester: BPS Books; 2002.

3) Leka S, Houdmont J. Occupational health psychology. Oxford: Wiley-Blackwell; 2010.

4) Weikert C. Occupational health psychology: empowerment, participation and health at work. Nottingham: The Institute of Work, Health \&Organisations; 2002.

5) Giga S. Occupational health psychology: flexibility, quality of working life and health. Nottingham: The Institute of Work, Health \&Organisations; 2003.

6) Occupational health psychology: european perspectives on research, education and practice. Castelo da Maia: ISMAI; 2007.
7) Schultz DP, Schultz SE. Psychology and work today: an introduction to industrial and organizational psychology. Upper Saddle River, NJ: Prentice Hall; 2002.

8) Strength, weakness, opportunities, threats in Information technology of India [Internet]. Naukri Hub. 2015 [cited 2017Dec1]. Available from: http://www.naukrihub.com/india/informationtechnology/swot-analysis.html

9) Information Technology Salary in India [Internet]. Naukri Hub. 2016 [cited 2017Dec7]. Available from: http://www.naukrihub.com/salary-in-india/ information-technology.html

10) Developments in IT-ITeS Sector [Internet]. Naukri Hub. 2015 [cited 2017Dec17]. Available from: http://www.naukrihub.com/india/informationtechnology/recent-developments/foreign.html

11) Bloomberg [Internet]. Bloomberg - Are you a robot? [cited 2017Dec19]. Available from: http:// www.businessweek.com/magazine/toc/05_25/ B393805it100.html

12) EMPLOYEE ASSISTANCE PROGRAMS [Internet]. Reference for Business. [cited 2017Dec20]. Available from: http://www. referenceforbusiness.com/small/Di-Eq/EmployeeAssistance-Programs.html

13) American Psychological Association. American Psychological Association; [cited 2017Dec21]. Available from: http://www.apa.org/pubs/journals/ ocp/index.aspx. Web. 6 Apr. 2012.

14) Health and Safety in the Manufacturing Sector, http://www.hse.gov.uk/manufacturing. Accessed 1 Dec. 2017.

15) A Brief History of Occupational Health Psychology. Occupational Health Psychology. 2016;

16) Research Methods in Occupational Health Psychology. Occupational Health Psychology. 2016; 